\title{
WANDA, a regional dynamic nitrogen model (With Aggregated Nitrogen DynAmics) for nitrate leaching from forests
}

\author{
Albert Tietema \\ Centre for Geo-ecological Research (ICG), Institute for Biodiversity and Ecosystem Dynamics (IBED)-Physical Geography, University of Amsterdam, Nieuwe Achtergracht \\ 166, 1018 WV Amsterdam, The Netherlands
}

Email: a.tietema@science.uva.nl

\begin{abstract}
Nitrate concentrations in recently infiltrated groundwater in forested areas in the Netherlands are slowly increasing towards the EU limit of $50 \mathrm{mg} \mathrm{NO} 1^{1-1}$. The origin of this nitrate is thought to be leaching from nitrogen $(\mathrm{N})$ saturated semi-natural ecosystems in these areas. To simulate nitrate leaching on a regional scale, the empirical model WANDA (a regional nitrogen model $\underline{\mathbf{W}}$ ith $\underline{\mathbf{A} g g r e g a t e d} \underline{\mathbf{N}} i t r o g e n \underline{\mathbf{D}} \mathbf{y} \underline{\mathbf{A}} \mathrm{mics})$ is introduced. The model is built around the concept that in forests the $\mathrm{C}: \mathrm{N}$ ratio of the organic layer is indicative of the amount of nitrate leaving the system in drainage. WANDA was tested on a regional dataset of an infiltration area of $10 \mathrm{~km}^{2}$. This infiltration area consisted of 350 forest stands draining to the catchment 'Edese Bos' used by a drinking water company. In 75 of the 350 forest stands the C:N ratio of the organic layer was measured. In 30 of these 75 stands, the nitrate concentrations below the rooting zone were measured. A hydrological model calculated water fluxes. The $\mathrm{C}: \mathrm{N}$ ratio of the 75 stands ranged from 15.7 to $31.3 \mathrm{~g} \mathrm{C} \mathrm{g}^{-1} \mathrm{~N}$. Scots pine stands had the highest $\mathrm{C}: \mathrm{N}$ ratios in the organic layer. Nitrate concentrations varied in the 30 stands from 0.6 to $70 \mathrm{mg} \mathrm{NO}_{3} 1^{-1}$. The nitrate concentrations in the Douglas fir stands were higher, and in the beech stands lower, than those observed in the locations with other tree species. WANDA predicted nitrate concentrations well, but improvements are required to simulate nitrate fluxes. The simulation of the water fluxes in WANDA is probably where more focussed modelling effort is now required.
\end{abstract}

Keywords: nitrogen, nitrate, forest, model, WANDA, C:N ratio, organic layer

\section{Introduction}

In parts of the Netherlands, groundwater is being used as a source of drinking water. Many infiltration areas are located in areas with limited agricultural activity. This minimises the effect of the excessive use of fertilisers as potential pollutants like nitrate (Tietema, 1999). However, also in recently infiltrated groundwater in these areas, nitrate concentrations are slowly increasing towards the EU limit of $50 \mathrm{mg} \mathrm{NO}_{3} \mathrm{l}^{-1}$. The origin of this nitrate is thought to be nitrate leaching from nitrogen $(\mathrm{N})$ saturated semi-natural ecosystems in these areas.

Ecosystems are $\mathrm{N}$ saturated if the $\mathrm{N}$ input exceeds $\mathrm{N}$ demand (Aber et al., 1989; Aber et al., 1998). Increased $N$ input by atmospheric deposition has raised the $\mathrm{N}$ availability in many Dutch ecosystems leading to $\mathrm{N}$ saturation. As a result, $\mathrm{N}$ is no longer the most important growth-limiting factor and excess $\mathrm{N}$ is leached out of the ecosystem as nitrate.
Gundersen et al. (1998a) presented the concept of N status for forested ecosystems; N-saturated sites have a high $\mathrm{N}$ status, N-limited sites a low $\mathrm{N}$ status. They found that $\mathrm{N}$ status for a specific forest stand could be described by a series of parameters characterising the nitrogen cycle. One of these parameters, the carbon-to-nitrogen $(\mathrm{C}: \mathrm{N})$ ratio of the organic layer, is relatively easy to measure and its role in assessing $\mathrm{N}$ demand at a plant and a microbe level is well known. In addition, the predictive role of $\mathrm{C}: \mathrm{N}$ ratio of the organic layer for $\mathrm{N}$ leaching at an ecosystem level has been described by several authors (McNulty et al., 1991; Tietema and Beier, 1995; Gundersen, 1995; Matzner and Grosholz, 1997; Dise et al., 1998a,b). The regional N model WANDA (a regional nitrogen model $\underline{\mathbf{W}}$ ith $\underline{\text { Aggregated }} \underline{\text { Nitrogen }}$ Dyn Amics) was developed on the basis of this concept. WANDA is an empirical model with a strong process-based background. 
In this study, the model WANDA is presented in detail. In addition, a regional dataset on nitrate leaching and the $C: N$ ratio of the organic layer in the forested stands of an infiltration area in the Netherlands is used to evaluate the model.

\section{Material and Methods}

\section{MODEL DESCRIPTION}

The $\mathrm{N}$ fluxes and transformations in WANDA are given as arrows in Fig. 1. For nitrate $\left(\mathrm{NO}_{3}^{-}\right)$and ammonium $\left(\mathrm{NH}_{4}^{+}\right)$, WANDA calculates the balance between availability and demand in a sequence given in the order of the arrows (1) to (11) in Fig. 1. In addition, the fluxes and transformations are given as equations in the text. The description, names and units of the parameters and variables can be found in Table 1. WANDA runs with annual time steps and is written in Turbo Pascal.

The availability of $\mathrm{NH}_{4}^{+}$in the soil is governed by ammonium deposition (Arrow 1 and Eqn. 1) and by mineralisation of $\mathrm{NH}_{4}$ from the organic $\mathrm{N}$ pool in the mineral soil, which is called Refractory Organic Matter (ROM) (Arrow 2 and Eqn. 2). Atmospheric deposition of $\mathrm{NH}_{4}^{+}$is

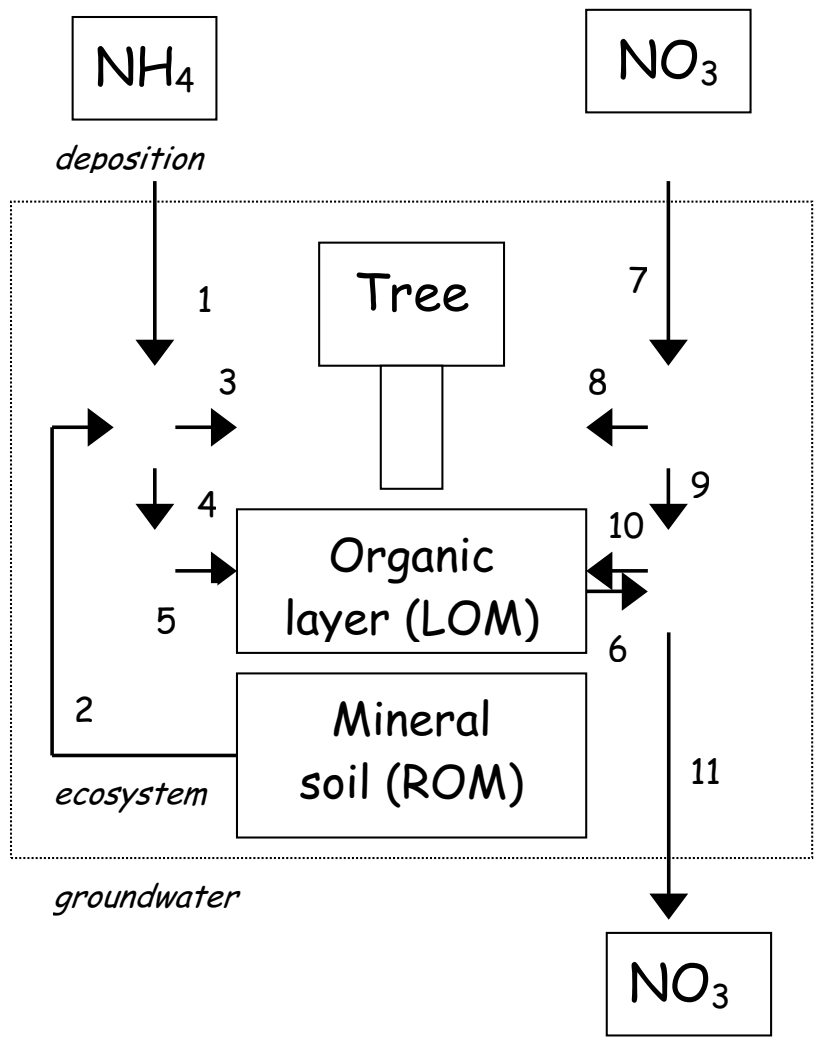

Fig. 1. Pools and fluxes in WANDA. The numbers $1-11$ next to the arrows correspond to the order of the sequence in which $N$ fluxes and transformations are treated in WANDA. the sum of the ammonium mass in both wet and dry deposition. Wet deposition is a constant and dry deposition is estimated as a fraction of the nitrogen mass in wet deposition and depends on tree species and age (Fig. 2a). ROM mineralisation follows a negative linear function of tree age (Fig. 2b).

$$
\begin{aligned}
& \text { IfAge }>\text { MinAgeWuMaxthenDepNH4 }=(\text { FiltNH4 }+1) * \\
& \text { PrecNH4 } \\
& \text { IfAge }>\text { MinAgeWuMaxthenDepNO3 }=(\text { FiltNO3 }+1) * \\
& \text { PrecNO3 }
\end{aligned}
$$

$$
\begin{aligned}
& \text { If Age }>\text { MaxAgeUptN then MinROMNH4 }=0 \\
& \text { ElseMinRomNH4=MinRomMax }((\text { AgeMaxAgeUptN }) * \\
& \text { MinRomMax })
\end{aligned}
$$

Tree growth depends primarily on available $\mathrm{NH}_{4}$. Net $\mathrm{N}$ demand by the trees follows a negative linear function of tree age, whereas $\mathrm{NH}_{4}$ is taken up preferentially by the trees to meet this demand (Arrow 3 and Eqn. 3).

$$
\begin{aligned}
& \text { If Age }>\text { MaxAgeUptN then PotUptNB=0 } \\
& \text { ElsePotUptN=MaxUptN-((AgeMaxAgeUptN) } \\
& * \text { MaxUptN) } \\
& \text { AvaiNH4=DepNH4 + MinRomNH4 } \\
& \text { If PotUptN>AvaiNH4 then UptNH4=AvaiNH4 } \\
& \text { Else UptNH4=PotUptN }
\end{aligned}
$$

If $\mathrm{NH}_{4}^{+}$availability exceeds tree $\mathrm{N}$ demand (Arrow 4), surplus $\mathrm{NH}_{4}^{+}$is available for uptake by Labile Organic Matter (LOM) (Arrow 5 and Eqn. 4). This N immobilisation is a function of the $\mathrm{C}: \mathrm{N}$ ratio in $\mathrm{LOM}$. All available $\mathrm{NH}_{4}^{+}$is taken up by LOM at high $\mathrm{C}: \mathrm{N}$ ratios, while at low $\mathrm{C}: \mathrm{N}$ ratios, no $\mathrm{NH}_{4}^{+}$is taken up (Fig. 3). At a C:N ratio of LOM between these two values, a linear fraction is taken up. These threshold $\mathrm{C}: \mathrm{N}$ ratios are set by calibration.

$$
\begin{aligned}
& \text { AvaiNH4=AvaiNH4-UptNH4B } \\
& \text { If CNratio }>\text { CNNH4max then UptNH4fr }=1 \\
& \text { Else if CNratio }<\text { CNNH4min then UptNH4fr }=0 \\
& \text { Else UptNH4fr }=(C N \text { ratio-CNNH4min })-(C N N H 4 \text { max- } \\
& \quad \text { CNNH4min }) \\
& \text { UptNH4Org=OpnNH4fr } * \text { AvaiNH4 }
\end{aligned}
$$

All $\mathrm{NH}_{4}^{+}$still available after all these processes is nitrified (Arrow 6 and Eqn. 5) and will leach out of the ecosystem (Arrow 11 and Eqn. 8).

$$
\text { Nitrif=AvaiNH4-UptNH4Org }
$$

The trees will take up $\mathrm{NO}_{3}^{-}$(Arrow 8 and Eqn. 6) in 
Table 1. Variables and parameters in the model. Equations in the model are given in the text.

Description
Variable and
parameter names

Carbon and Nitrogen Pools and fluXes

Amount of $\mathrm{N}$ in trees

Amount of $\mathrm{N}$ in LOM

Amount of $\mathrm{C}$ in LOM

Accumulation rate of carbon in LOM

$\mathrm{CN}$ ratio of $\mathrm{LOM}$

Nitrification

Leaching of NO3

UPTAKE AND IMMOBILISATION PARAMETERS

Tree age

Potential tree $\mathrm{N}$ uptake

Maximum tree $\mathrm{N}$ uptake

$\mathrm{NH} 4$ or NO3 tree uptake

Available NH4 or NO3

Maximum $\mathrm{CN}$ ratio in $\mathrm{LOM}$ at which all available $\mathrm{NH} 4$ or $\mathrm{NO} 3$ is immobilised

Fraction immobilised of available NH4 or NO3

Minimum $\mathrm{CN}$ ratio in LOM at which no NH4 or NO3 is immobilised

Fraction of available NH4 or NO3 immobilised by the micro organisms

N DEPOSITION PARAMETERS AND FLUXES

Maximum tree age at which potential tree $\mathrm{N}$ uptake and ROM mineralisation equals zero

Minimum tree age at which water uptake is maximal

Amount of ammonium and nitrate in precipitation

Amount of ammonium and nitrate in deposition

Filtering factor for ammonium and nitrate

WATER USE PARAMETERS

Amount of precipitation

Water use by the trees

Maximum water use by the trees

Water use at tree age zero

Maximum age at which water use is zero

Minimum age at which water use is maximal

Minimum age at which water use is minimal

Maximum age at which water use is maximal

Maximum age at which water use is minimal

Amount of drainage

MODEL PARAMETERS

Timestep
TreeN

OrgN

$\mathrm{OrgC}$

Cacc

Cnratio

Nitrif

LeachNO3

Age

PotUptN

MaxUptN

UptNH4 UptNO3

AvaiNH4 AvaiNO3

CNNH4max CNNO3max

UptNH4fr UptNO3fr

CNNH4min CNNO3min

UptNH4Org UptNO3Org

MaxAgeUptN

MinAgeWuMax

Prec(NH4) Prec(NO3)

Dep(NH4) Dep(NO3)

Filt(NH4) Filt(NO3)

$\mathrm{mol} \mathrm{N} \mathrm{m}{ }^{-2}$

$\mathrm{mol} \mathrm{N} \mathrm{m}{ }^{-2}$

$\mathrm{mol} \mathrm{C} \mathrm{m}{ }^{-2}$

$\mathrm{mol} \mathrm{C} \mathrm{m}{ }^{-2} \mathrm{yr}^{-1}$

$\mathrm{mol} \mathrm{C} \mathrm{mol}{ }^{-1} \mathrm{~N}$

$\mathrm{mol} \mathrm{N} \mathrm{m}{ }^{-2} \mathrm{yr}^{-1}$

$\mathrm{mol} \mathrm{N} \mathrm{m}{ }^{-2} \mathrm{yr}^{-1}$

yr

$\mathrm{mol} \mathrm{N} \mathrm{m}{ }^{-2} \mathrm{yr}^{-1}$ $\mathrm{mol} \mathrm{N} \mathrm{m}{ }^{-2} \mathrm{yr}^{-1}$ $\mathrm{mol} \mathrm{N} \mathrm{m}{ }^{-2} \mathrm{yr}^{-1}$ $\mathrm{mol} \mathrm{N} \mathrm{m}{ }^{-2}$

mol C mol-1 $\mathrm{N}$ unitless

mol C mol-1 $\mathrm{N}$ unitless

$\begin{array}{ll}\text { Precip } & \mathrm{mm} \mathrm{yr}^{-1} \\ \text { WatUse } & \mathrm{mm} \mathrm{yr}^{-1} \\ \text { WuAgeMax } & \mathrm{mm} \mathrm{yr}^{-1} \\ \text { WuAge0 } & \mathrm{mm} \mathrm{yr}^{-1} \\ \text { MaxAgeWu0 } & \mathrm{yr} \\ \text { MinAgeWuMax } & \mathrm{yr} \\ \text { MinAgeWuMin } & \mathrm{yr} \\ \text { MaxAgeWuMax } & \mathrm{yr} \\ \text { MaxAgeWuMin } & \mathrm{yr} \\ \text { Drain } & \mathrm{mm} \mathrm{yr}\end{array}$

atmospheric deposition (Arrow 7) if the $\mathrm{NH}_{4}^{+}$availability is not enough to meet net tree $\mathrm{N}$ demand. Atmospheric deposition of $\mathrm{NO}_{3}^{-}$is calculated as for $\mathrm{NH}_{4}^{+}$but with different parameter values.
PotNO3=PotUptN-UptNH4

If PotNO3 $>$ DepNO3 then $U p t N O 3=D e p N O 3$

Else UptNO3=PotUptN

AvaiNO3 $=$ DepNO3-UptNO3 
(a)

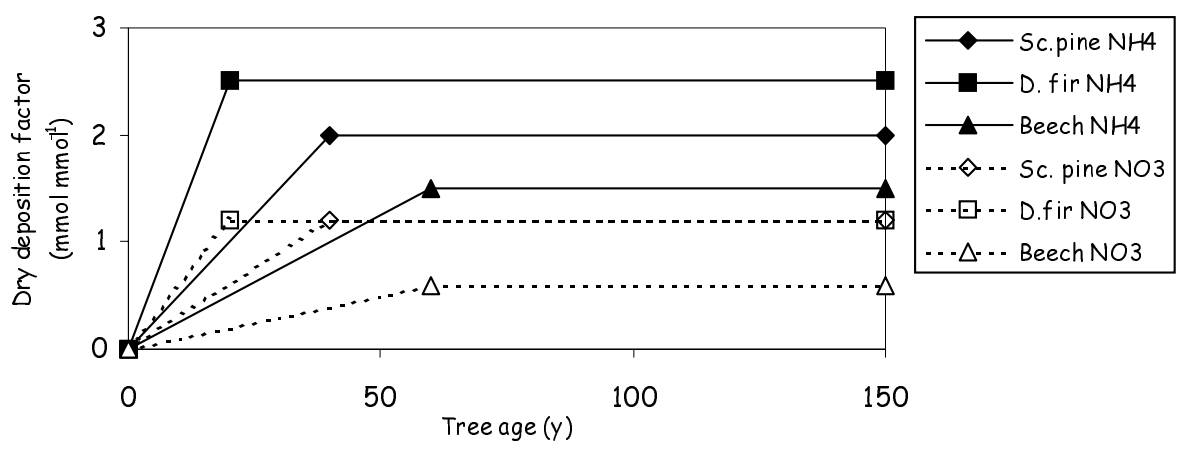

(b)
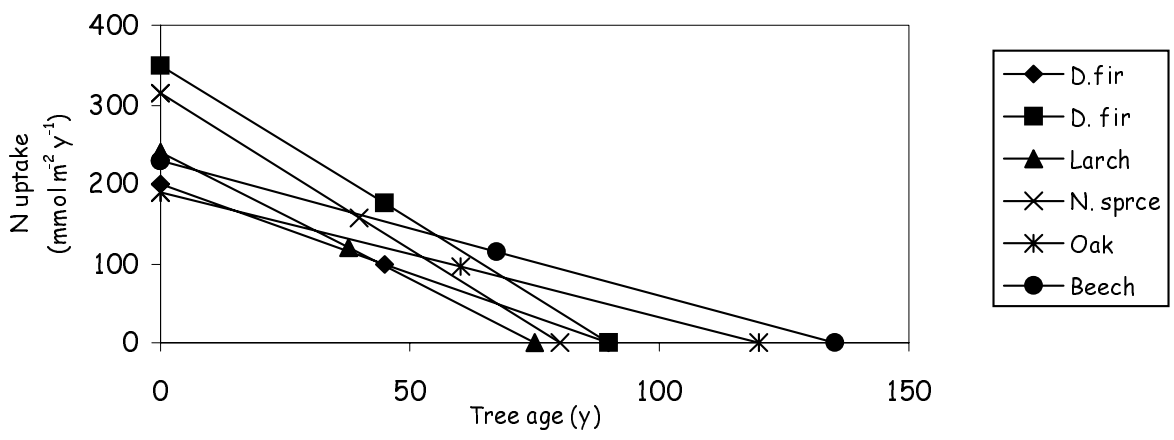

(c)
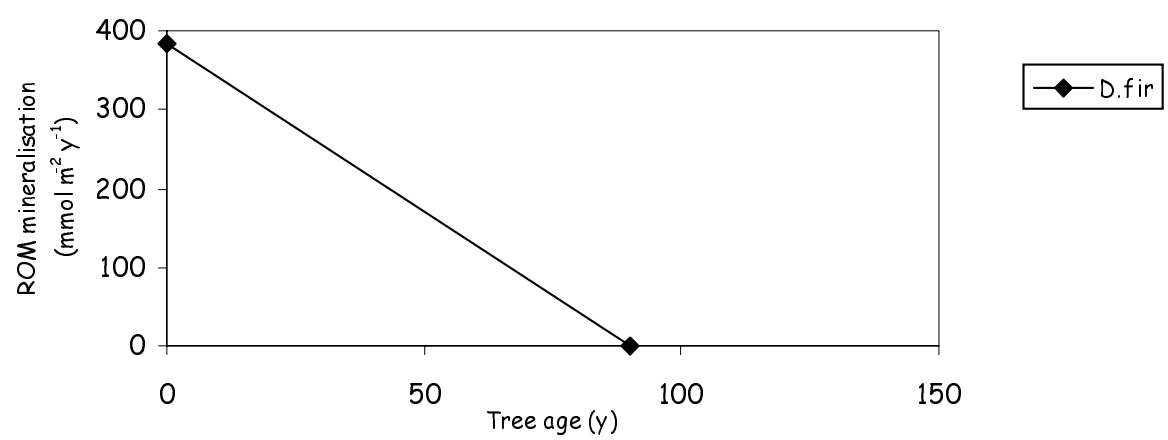

(d)

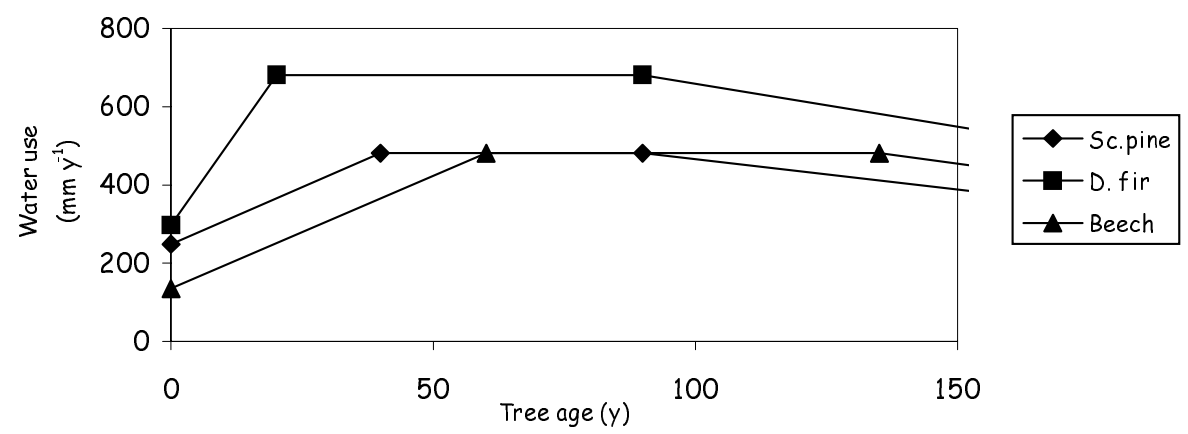

Fig. 2. The relation between dry deposition factor of $\mathrm{NH}_{4}^{+}$and $\mathrm{NO}_{3}^{-}$(panel a), tree $\mathrm{N}$ uptake for the different tree species (panel b), ROM mineralisation for Douglas fir (panel c) and annual water use (panel d) with tree age for Scots pine, Douglas fir and beech in WANDA.

The $\mathrm{NO}_{3}^{-}$left over (Arrow 9) is available for LOM uptake (Arrow 10 and Eqn. 7) according to the same relationship with the $\mathrm{C}: \mathrm{N}$ ratio of $\mathrm{LOM}$ as $\mathrm{NH}_{4}^{+}$but with different parameters. The amount of $\mathrm{NO}_{3}{ }^{-}$still available will leach out of the system together with the nitrified $\mathrm{NH}_{4}^{+}$(Arrow 11 and Eqn. 8).
If CNratio $<$ CNNO3max then UptNO3fr-1

Else if CNratio $<C N N O 3 m i n$ then UptNO3fr $=0$

Else UptNO3fr $=(C N$ ratio-CNNO3min $)-(C N N O 3 \max -$ CNNO3min)

UptNO3Org=OpnNO3fr*AvaiNO3 


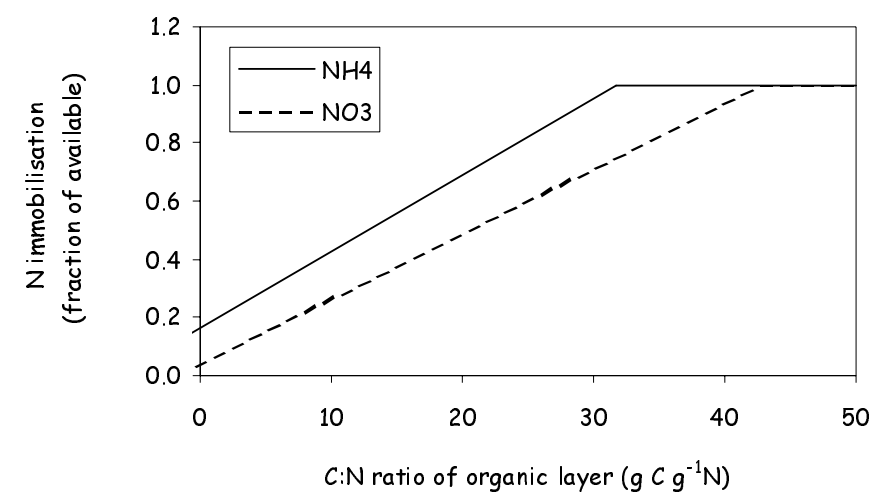

Fig. 3. The relation between the $C: N$ ratio in the organic layer (LOM) and $\mathrm{NH}_{4}^{+}$and $\mathrm{NO}_{3}^{-}$immobilisation in LOM as a fraction of available $\mathrm{NH}_{+}^{+}$and $\mathrm{NO}_{3}^{-}$. This relation is used for all tree species. The C: $\mathrm{N}$ ratio at which $\mathrm{NH}_{4}^{+}$and $\mathrm{NO}_{3}{ }_{3}^{-}$immobilisation becomes 0 and 1 , together with the maximum ROM mineralisation rate (Fig. $2 c$ ) were calculated by parameter optimisation.

\section{LeachNO3 $=($ AvaiNO3-UptNO3Org $)+$ Nitrif}

In WANDA, the C storage in LOM is calculated because the $\mathrm{C}: \mathrm{N}$ ratio is important in regulating $\mathrm{N}$ immobilisation in LOM. In this first version of WANDA, the amount of $\mathrm{C}$ stored depended on the amount of $\mathrm{N}$ taken up by LOM, which assumes a constant $\mathrm{C}: \mathrm{N}$ ratio in LOM (Eqn. 9).

\section{Cacc $=$ CNratio $*(($ UptNH4Org $*$ TimeStep $)+($ UptNO3Org* TimeStep)

The amount of drainage is calculated (Eqn. 10) as the difference between the precipitation amount and the water use of the vegetation, and the water use is a function of tree species and age (Fig. 2d). Total C and $\mathrm{N}$ in LOM and $\mathrm{N}$ in trees, as well as tree age are integrated (Eqn. 11).

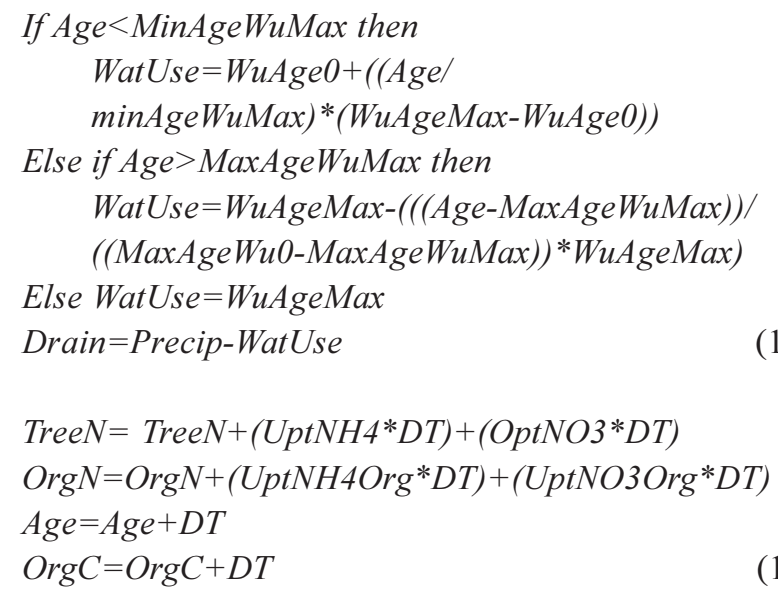

$\operatorname{TreeN}=\operatorname{TreeN}+\left(\mathrm{UptNH}^{*} * \mathrm{DT}\right)+(\mathrm{OptNO} 3 * \mathrm{DT})$

$\operatorname{OrgN}=\operatorname{OrgN}+\left(\mathrm{UptNH}_{4} \mathrm{Org} * \mathrm{DT}\right)+\left(\mathrm{UptNO} \mathrm{Org}^{*} \mathrm{DT}\right)$

Age $=$ Age $+D T$

$\operatorname{OrgC}=\operatorname{Org} C+D T$

\section{PARAMETERS}

The dry deposition factor is a function of $\mathrm{N}$ in precipitation and is dependent on tree species and age (Fig. 2a). This relationship was assumed to be similar for Scots pine (Pinus sylvestris) and larch (Larix leptolepis), for Douglas fir (Pseudotsuga menziesii) and Norway spruce (Picea abies) and for oak (Quercus robur) and beech (Fagus sylvatica). The dry deposition factor differed for $\mathrm{NH}_{4}{ }^{+}$and $\mathrm{NO}_{3}{ }^{-}$based on the co-deposition of $\mathrm{NH}_{4}^{+}$and $\mathrm{SO}_{4}^{2-}$ (Van Breemen et al., 1982) (Fig. 2a).

The relationship between net $\mathrm{N}$ tree demand and tree age was obtained from forestry yield tables (Janssen et al., 1996). The growth curves were recalculated from bole wood volumes and net $\mathrm{N}$ accumulation in the whole tree. A linear regression through the data points yielded a linear function that was used in the model (Fig. 2b).

The first model applications showed that tree demand could not be met by atmospheric deposition of $\mathrm{N}$ only. To solve this problem $\mathrm{N}$ mineralisation from the ROM pool was introduced as an additional $\mathrm{N}$ source (Cosby et al., 1997). Because this $\mathrm{N}$ mineralisation appeared closely related to ecosystem growth (Tietema et al., 1998), a comparable relation with tree age was used as for $\mathrm{N}$ demand. Moreover, a similar age was assumed at which both net tree $\mathrm{N}$ demand and ROM mineralisation became zero (Fig. 2c). The $\mathrm{C}: \mathrm{N}$ ratio of organic matter was recognised as a good indicator of microbial $\mathrm{N}$ requirement and of $\mathrm{N}$ status of an ecosystem. A step function was introduced in WANDA (Fig. 3) where the $\mathrm{C}: \mathrm{N}$ ratio of LOM determined the fraction of available $\mathrm{NH}_{4}^{+}$and $\mathrm{NO}_{3}{ }^{-}$taken up by the microbes. Below a certain $\mathrm{C}: \mathrm{N}$ ratio, which is set by calibration, no $\mathrm{NH}_{4}^{+}$or $\mathrm{NO}_{3}{ }^{-}$was taken up, while at a $\mathrm{C}: \mathrm{N}$ ratio of LOM above a calibrated value all available $\mathrm{NH}_{4}^{+}$or $\mathrm{NO}_{3}^{-}$was taken up. At intermediate $\mathrm{C}: \mathrm{N}$ ratios uptake increased linearly with $\mathrm{C}: \mathrm{N}$ ratio.

The value of these four parameters, two for $\mathrm{NH}_{4}^{+}$and two for $\mathrm{NO}_{3}^{-}$(Fig. 3), and of the maximum ROM mineralisation rate (Fig. 2c) was determined by parameter optimisation using the relationship between the $\mathrm{C}: \mathrm{N}$ ratio of the organic layer and $\mathrm{NO}_{3}^{-}$leaching described by Gundersen (1995). To get a combination of the parameter values, the $\mathrm{NO}_{3}{ }^{-}$ leaching numbers calculated by WANDA were fitted on $\mathrm{NO}_{3}{ }^{-}$leaching numbers predicted by this relationship.

Water use by the vegetation depends on tree species and tree age (Fig. 2d). The relation is based on a maximum water use after canopy closing and a decreasing water use until the moment of minimized growth. Maximum water use for each tree species, on these sandy soils was calculated with the forest hydrological model SWIF (으이 Water In Forests) (Tiktak and Bouten, 1992). 


\section{FIELD MEASUREMENTS AND SIMULATIONS}

The infiltration area 'de Driesprong' $\left(10 \mathrm{~km}^{2}\right)$ is north of the town of Ede in the centre of The Netherlands. The groundwater retention time, within the infiltration area, is 25 years. Land use of the infiltration area is mainly forest $(55 \%)$ and heathland $(25 \%)$, while the rest is urban and arable land. The forested area consists of three forests: 'Edese bos', 'Roekelse bos' and 'de Valouwe'. Scots pine is the dominant tree species ( $47 \%$ of the total forested area), followed by larch (15\%), Douglas fir (12\%), beech (12\%) and Norway spruce (5\%).

In 75 out of 350 forest stands, the $\mathrm{C}: \mathrm{N}$ ratio of the organic layer was determined. These 75 stands consisted of Scots pine (28 stands) Douglas fir (15), larch (9), Norway spruce (9), beech (10) and oak (4). In each stand, four samples of the organic layer were taken by means of a PVC tube (length $=20 \mathrm{~cm}$, internal diameter $=11.8 \mathrm{~cm}$ ). Woody particles and roots $(>2 \mathrm{~mm}$ ) were removed, and the samples were dried at $70{ }^{\circ} \mathrm{C}$ and weighed. After grinding, the four samples of each stand were bulked and $\mathrm{C}$ and $\mathrm{N}$ concentrations were determined in triplicate subsamples with a $\mathrm{CN}$ analyser. The $\mathrm{C}: \mathrm{N}$ ratio $\left(\mathrm{g} \mathrm{C} \mathrm{g}^{-1} \mathrm{~N}\right)$ was calculated as the ratio between the $\mathrm{C}$ and $\mathrm{N}$ storage $\left(\mathrm{g} \mathrm{m}^{-2}\right)$.

Statistical differences between forests and tree species were tested with a one-way analysis of variance (ANOVA). A Tukey t-test was used to test the significance between means. Significant differences between means are given for $\mathrm{p}<0.05$, unless otherwise noted.

In 30 of the 75 forest stands, $\mathrm{NO}_{3}^{-}$leaching was determined. Stands of Scots pine (10), Douglas fir (5), larch (5), Norway spruce (5) and beech (5) were chosen to cover the whole range of $\mathrm{C}: \mathrm{N}$ ratios and tree ages. Soil samples at three depths $(1.20 \mathrm{~m}, 1.40 \mathrm{~m}$ and $1.60 \mathrm{~m})$ were taken in January 1999. In each stand two soil cores were taken, which were mixed per depth. After determining the moisture content, the samples were extracted with $\mathrm{H}_{2} \mathrm{O}$ in a $1: 1$ extraction ratio and filtered $(0.2 \mu \mathrm{m})$. Nitrate concentrations were measured by automated colometry using an autoanalyser. To translate $\mathrm{NO}_{3}^{-}$concentrations into $\mathrm{NO}_{3}^{-}$ leaching, water fluxes were calculated with the hydrological model SWIF. Daily precipitation amounts for the previous four years at the neighbouring monitoring site Speuld were used as input. Tree-specific input parameters for describing throughfall and transpiration were used to differentiate between tree species. Soil physical parameters characteristic for loamy, sandy podsols were used. Nitrate leaching was calculated as the product of the mean $\mathrm{NO}_{3}{ }^{-}$concentration of all three depths, and the calculated water flux at a depth of $1.50 \mathrm{~m}$ for the year 1998. WANDA was applied on all 30 stands to compare the simulated results with measured nitrate concentrations and modelled water fluxes.

\section{Results and Discussion}

\section{FIELD MEASUREMENTS}

The measured $\mathrm{C}: \mathrm{N}$ ratios in the organic layer of the 75 forest stands varied from 15.7 to 31.3 . The $\mathrm{C}: \mathrm{N}$ ratio varied significantly per tree species (Fig. 4a). The C:N ratios in the Scots pine stands were significantly higher than in the Douglas fir, oak stands and beech stands. No other significant differences in $\mathrm{C}: \mathrm{N}$ ratio between the tree species were found (Fig. 4a).

Heterogeneity in the $\mathrm{C}: \mathrm{N}$ ratio in the forested area is evident, even in a limited area of only $10 \mathrm{~km}^{2}$. The C:N ratio in the organic layer of the Scots pine stands varied from 18.9 to 31.3 . The 'Roekelse bos' showed significantly higher C:N ratios (Fig. 4b). This is probably caused by significant differences in the location and age of the three forests. The 'Roekelse bos' is on the top of a ice-pushed moraine, while the other two forests are on a lower part of the moraine; this leads to differences in chemical composition of the minerals. However, differences in landuse before it was afforested might have caused this discrepancy. Variation in $\mathrm{N}$ deposition between the stands is expected to be relatively small given the small area. The data of the Scots pine stands showed a clear effect of age on the build-up of the organic layer. Total storage of $\mathrm{C}$ as well as $\mathrm{N}$ in the forest floor was significantly correlated with tree age (Fig. 5), indicating a linear build-up in time of the organic layer.

The measured $\mathrm{NO}_{3}{ }^{-}$concentrations varied from $1.7 \mathrm{mg}$ $\mathrm{NO}_{3} 1^{-1}$ to $75.3 \mathrm{NO}_{3} \mathrm{mg} \mathrm{l}^{-1}$ (Fig. 6). The highest $\mathrm{NO}_{3}^{-}$ concentrations were measured in the Douglas fir locations, whereas the lowest $\mathrm{NO}_{3}{ }^{-}$concentrations were measured in the beech locations. Ammonium concentrations were less than $8 \mathrm{mg} \mathrm{l}^{-1}$ at all depths (results not shown).

As with the $\mathrm{C}: \mathrm{N}$ ratio, the spatial variability of the $\mathrm{NO}_{3}{ }^{-}$ concentrations was high, which indicates high variability in $\mathrm{N}$ status across this relatively small area. The low $\mathrm{NO}_{3}^{-}$ concentrations in beech stands are a well-known phenomenon. This is often explained by the low decomposition rate of the beech litter leading to thick organic layers and to the production of phenolic substances preventing nitrification (Handley, 1961).

\section{WANDA}

In WANDA, it is assumed that the $\mathrm{NH}_{4}^{+}$not taken up by the trees and the microbes will be nitrified and will eventually leach as $\mathrm{NO}_{3}^{-}$. To evaluate the effectiveness of WANDA, $\mathrm{NO}_{3}{ }^{-}$concentrations in leachate calculated by WANDA have to be compared with the measurements of dissolved inorganic $\mathrm{N}$ (DIN), which is the sum of $\mathrm{NO}_{3}^{-}-\mathrm{N}$ and $\mathrm{NH}_{4}^{+}-$ 
(a)

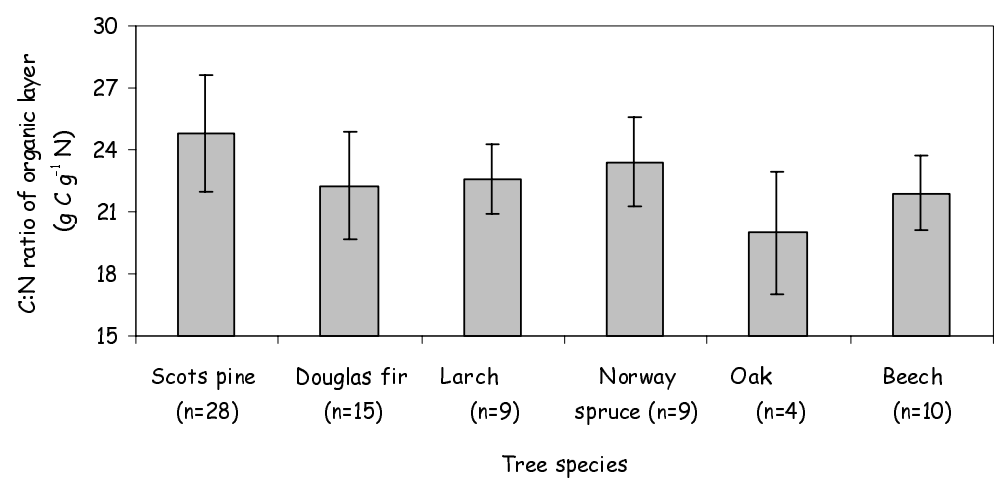

(b)

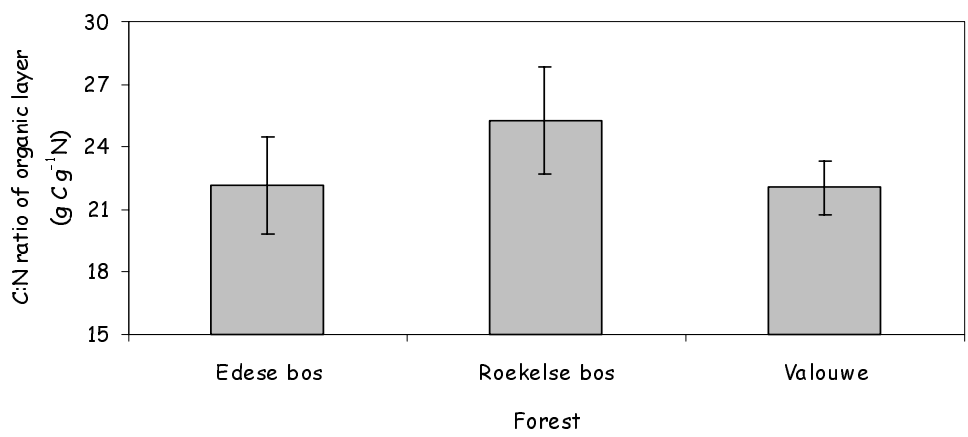

Fig. 4. C:N ratio of the organic layer in 75 forest stands as a function of tree species (panel a) and the location in the three forests occurring in the infiltration area (panel b). Bars show means with standard deviation.

(a)

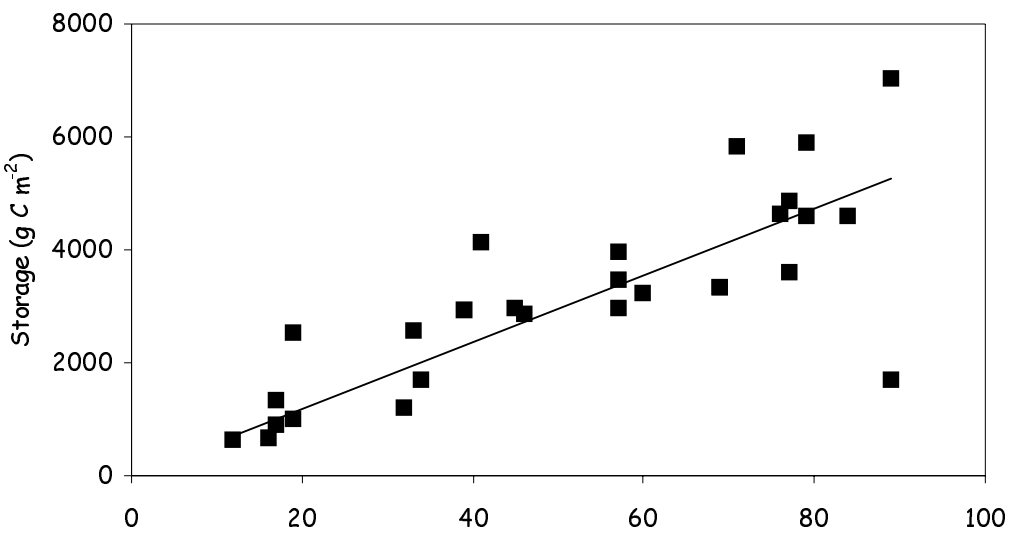

(b)

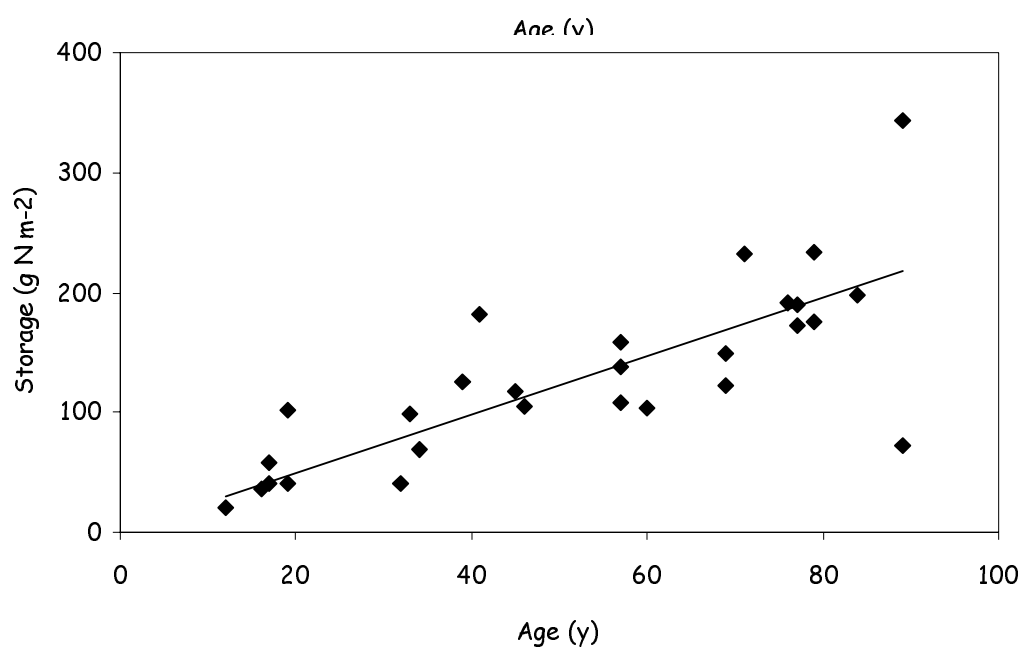

Fig. 5. Total storage of $C$ (panel a) and $N$ (panel b) in the organic layer of Scots pine stands as a function of tree age. 


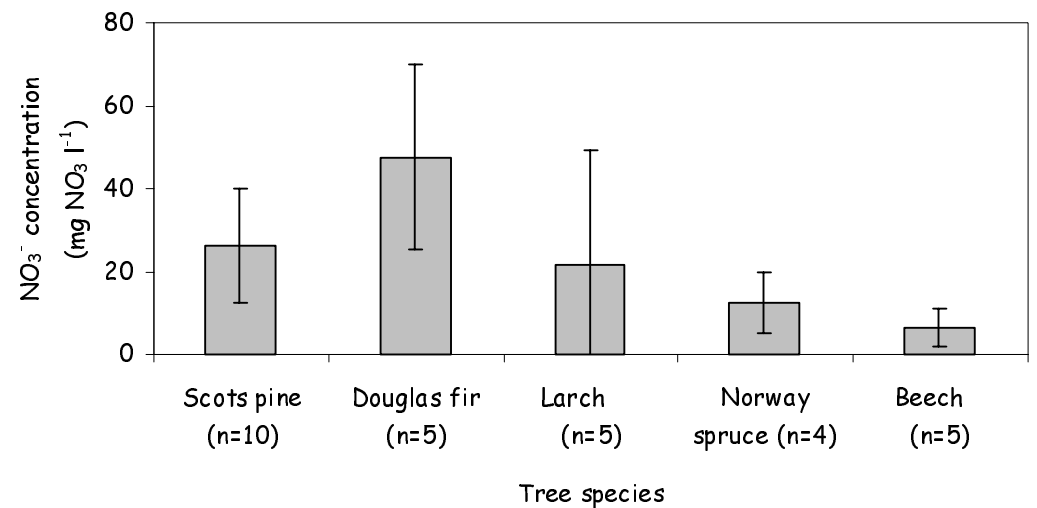

Fig. 6. Nitrate concentrations in 30 forest stands as a function of tree species. Bars show means with standard deviation.

$\mathrm{N}$, expressed as $\mathrm{mg} \mathrm{NO}_{3}^{-}-\mathrm{N}^{-1}$. WANDA calculates DIN fluxes, while the observations consisted of DIN concentration measurements. There are two ways of validation. The DIN fluxes simulated by WANDA can be converted to DIN concentrations using the relatively simple soil water model incorporated in WANDA. Thus, the model results can be compared directly with the measurements. These WANDA simulated DIN concentrations are significantly correlated with the measurements and the regression line is close to the 1:1 line (Fig. 7a). Another possibility is to compare DIN fluxes modelled by WANDA with observed DIN fluxes. This requires the use of a complex hydrological model to obtain water fluxes to transform measured DIN concentrations into DIN fluxes. However, these simulated and measured DIN fluxes are not correlated at all $\left(\mathrm{r}^{2}=0.004\right)$ (Fig. 7b).

(a)

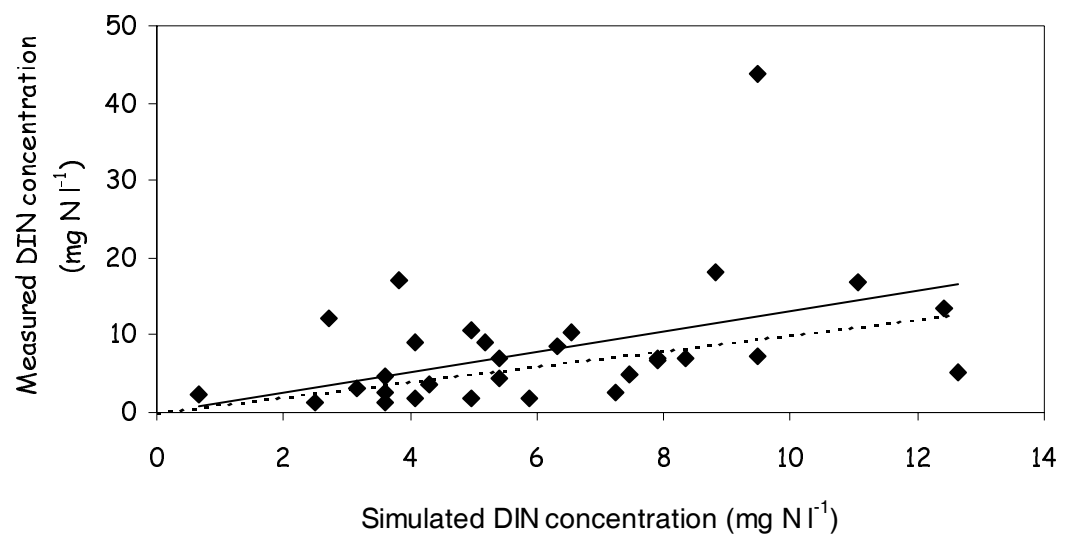

(b)

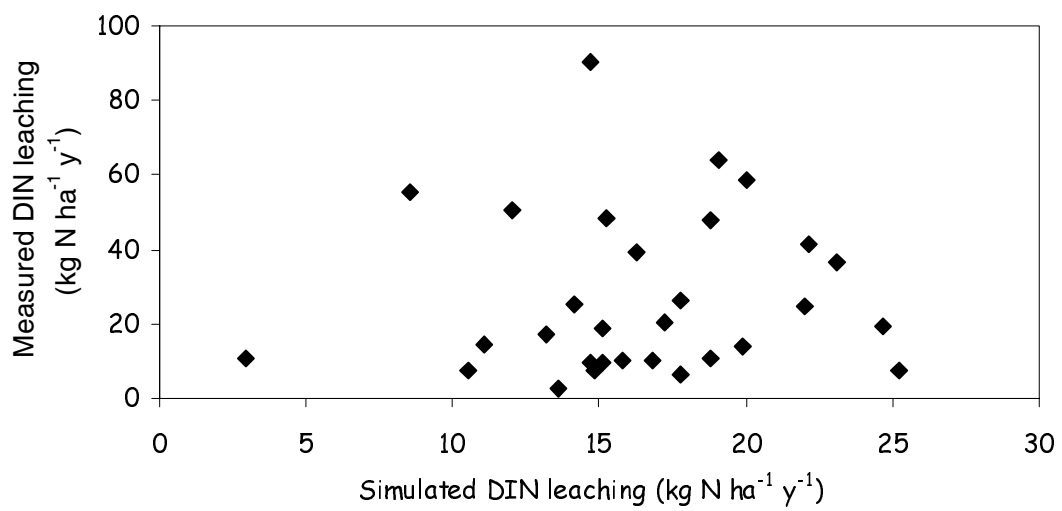

Fig. 7. A comparison between $\mathrm{NO}_{3}^{-}$concentrations (panel a) and fluxes (panel b) modelled with WANDA and measured. 
This discrepancy was probably caused by the method of water flux calculation. Using similar models would be a solution, but the soil water model in WANDA was chosen such that its complexity matched the complexity of the $\mathrm{N}$ model in WANDA. A more straightforward solution would be to use the relationship between $\mathrm{C}: \mathrm{N}$ ratio of the organic layer with the $\mathrm{NO}_{3}{ }^{-}$concentration for parameter optimisation instead of the relation with $\mathrm{NO}_{3}^{-}$leaching. This solution would make the use of a hydrological model unnecessary. However, fluxes of $\mathrm{NO}_{3}^{-}$are of more relevance to the ecosystem. Callesen et al., (1999) presented a Danish regional dataset on $\mathrm{NO}_{3}{ }^{-}$concentration below forests, where indeed $\mathrm{NO}_{3}{ }^{-}$concentrations were correlated with the $\mathrm{C}: \mathrm{N}$ ratio of the organic layer. However, the measurements were collected on a relatively small area within the same year and, thus, with a comparable hydrological regime. Large water fluxes in for instance a relatively wet year will decrease the $\mathrm{NO}_{3}{ }^{-}$concentration, whereas it is expected that the $\mathrm{NO}_{3}^{-}$ flux will be influenced only by changed mobilisation and immobilisation processes due to the changed moisture conditions. This fluctuation will only be small compared to the overall effect of the $\mathrm{N}$ status.

The C:N ratio of the organic layer is a relatively easy-tomeasure quantity that is correlated with the $\mathrm{N}$ status of an ecosystem. In infiltration area 'de Driesprong', C: $\mathrm{N}$ ratio was measured in 75 out of 350 forested stands. The C:N ratios of the other stands were obtained by weighted randomised sampling, extrapolation and linear regression (Tietema, 1999). For larger regions, a model can be used to estimate the C:N ratio of the organic layer. Kros et al., (2003) used WANDA for modelling $\mathrm{NO}_{3}^{-}$leaching at a national scale. In this application, the $\mathrm{C}: \mathrm{N}$ ratio of the organic layer of the forests was calculated for each $250 \times 250 \mathrm{~m}^{2}$ cell of a grid covering the Netherlands using a multiple regression relation based on measured $\mathrm{C}: \mathrm{N}$ ratios of the organic layer, tree species, soil type and tree age.

This is a first version of WANDA. One of the possible future improvements would be to make the $\mathrm{C}: \mathrm{N}$ ratio dynamic in the model. In this version the $\mathrm{C}: \mathrm{N}$ ratio is kept constant which makes the model of limited temporal use. The C:N ratio of the organic layer is correlated with the $\mathrm{N}$ status of an ecosystem and the $\mathrm{N}$ status changes as a result of $\mathrm{N}$ deposition. The most likely solution would be to make the $\mathrm{C}: \mathrm{N}$ ratio a function of $\mathrm{N}$ deposition. Other improvements would be to introduce a more sophisticated $\mathrm{C}$ model, a more detailed description of the expected nitrate flux after clear-cutting depending on $\mathrm{N}$ status and a more detailed relationship between the $\mathrm{C}: \mathrm{N}$ ratio of the organic layer and nitrate leaching. Gundersen et al., (1998b) split

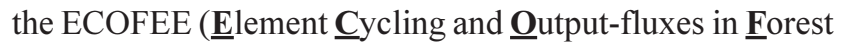
Ecosystems in Europe) dataset into forested sites with C:N ratios in the organic layer $>30,25$ to 30 , and $<25$, to separate low, moderate, and high nitrate leaching risk, respectively. The majority (22 out of 30) of the sites in 'de Driesprong' have a $\mathrm{C}: \mathrm{N}$ ratio $<25$. Using only these sites would give a completely different relationship between $\mathrm{C}: \mathrm{N}$ ratio and nitrate leaching. Another possibility would be to look at different tree species or take other factors like $\mathrm{N}$ deposition into account (Dise et al., 1998a).

An important unknown is the spatial heterogeneity of the $\mathrm{C}: \mathrm{N}$ ratio of the organic layer and of $\mathrm{NO}_{3}{ }^{-}$concentrations underneath the rooting zone. No data are currently available describing the variation of these parameters within a forest stand, while it is known that $\mathrm{N}$ deposition in a stand can vary largely as a result of crown characteristics. Raat et al., (2002) measured a coefficient of variation of $24 \%$ in $\mathrm{N}$ deposition in a Douglas fir stand. Long-term differences in $\mathrm{N}$ deposition within a stand will result in differences in $\mathrm{N}$ status within that stand so that the number of samples of the organic layer and of the soil cores as were used in this study is insufficient to characterise the whole stand.

WANDA is an empirical N model with a strong processbased background. It is positioned between dynamic $\mathrm{N}$ models which operate on at the plot scale like NUCSAM (Kros, 2003), NICCCE (Van Dam and Van Breemen, 1995) and TRACE (Currie et al., 1999) or small catchment scale models like MERLIN (Cosby et al., 1997), and empirical N models that are built for use at the national scale such as SMART2 (Kros, 2004). WANDA is aimed at the intermediate scale of regions, without losing the underlying processes. It is applicable at a scale comparable to INCA (Whitehead et al., 1998), but is more focused on forest systems. There is a strong need for $\mathrm{N}$ models that cover this regional scale for local policy makers and locally operating companies like water companies. WANDA fits this gap.

This first exercise showed that WANDA was able to simulated nitrate concentrations, but improvements are required to simulate nitrate fluxes. The simulation of the water fluxes in WANDA is probably where more modelling effort is required.

\section{Acknowledgements}

This study was made possible by financial support of NUON-WATER, the EU (Project EVK1-1999-00011) and the University of Amsterdam. The city council of Ede is thanked for permission to work in 'de Driesprong'.

\section{References}

Aber, J.D., Nadelhoffer, K.J., Steudler, P. and Melillo, J.M., 1989. Nitrogen saturation on northern forest ecosystems. Bioscience, 39, 378-386. 
Aber, J.D., McDowell, W.H., Nadelhoffer, K.J., Magill, A., Berntson, G., Kamakea, M., McNulty, S.G., Currie, W.S., Rustad, L.E. and Fernandez, I.J., 1998. Nitrogen saturation in temperate forest ecosystems - Hypotheses revisited. Bioscience, 48, 921 934.

Callesen, I., Raulund-Rasmussen, K., Gundersen, P. and Stryhn, H., 1999. Nitrate concentrations in soil solutions below Danish forests. Forest Ecol. Manage., 114, 71-82.

Cosby, B.J., Ferrier, R.C., Jenkins, A., Emmett, B.A., Wright, R.F. and Tietema, A., 1997. Modelling the ecosystem effects of nitrogen deposition: Model of Ecosystem Retention and Loss of Inorganic Nitrogen (MERLIN). Hydrol. Earth Syst. Sci., 1, $137-158$

Currie, W.S., Nadelhoffer, K.J. and Aber, J.D., 1999. Soil detrital processes controlling the movement of $15 \mathrm{~N}$ tracers to forest vegetation. Ecol. Appl. 9, 87-102.

Dise, N.B., Matzner, E. and Forsius, M., 1998a. Evaluation of organic horzon $\mathrm{C}: \mathrm{N}$ ratio as an indicator of nitrate leaching in conifer forests across Europe.rogen pools and fluxes from European forest ecosystems. Environ. Pollut., 102, 453-456.

Dise, N.B., Matzner, E. and Gundersen, P., 1998b. Synthesis of nitrogen pools and fluxes from European forest ecosystems. Water Air Soil Pollut., 105, 143-154.

Gundersen, P., 1995. Nitrogen deposition and leaching in European forests - preliminary results from a data compilation. Water Air Soil Pollut., 85, 1179-1184.

Gundersen, P., Emmett, B.A., Kjønaas, O.J., Koopmans, C.J. and Tietema A., 1998a. Impact of nitrogen deposition on nitrogen cycling: a synthesis of NITREX-data. Forest Ecol. Manage., 101, 37-55.

Gundersen, P., Callesen, I. and de Vries, W., 1998b. Nitrate leaching in forest ecosystems is controlled by forest floor $\mathrm{C} / \mathrm{N}$ ratio. Environ. Pollut., 102, 403-407.

Janssen, J.J., Sevenster, J. and Faber, P.J., 1996. Opbrengsttabellen voor belangrijke boomsoorten in Nederland. IBN-rapport 221, Wageningen, 202pp.

Handley, W.R.C., 1961. Further evidence for the importance of residual leaf protein complexes in litter decomposition and the supply of nitrogen for plant growth. Plant Soil, 15, 37-73.

Kros, J., 2002. Evaluation of biogeochemical models at local and regional scale. PhD-thesis. University of Wageningen, Wageningen, The Netherlands. 284pp.
Kros, J., Tietema, A., Mol-Dijkstra, J.P. and De Vries, W., 2004. Quantification of nitrate leaching from forest soils on a national scale. Hydrol. Earth Syst. Sci., 8, 813-822.

Matzner, E. and Grosholz, C., 1997. Relationship between $\mathrm{NO}_{3}$ output, $\mathrm{C} / \mathrm{N}$ ratios of the humus layer and $\mathrm{N}$-input in Central European spruce forest (Picea abies Karst.) ecosystems. Forstw. Cbl., 116, 39-44.

McNulty, S.G., Aber, J.D. and Boone, R.D., 1991. Spatial changes in forest floor and foliar chemistry of spruce-fir forests across New England. Biogeochemistry 14, 13-29.

Raat, K., Draaijers, G.P.J., Schaap, M.G., Tietema, A. and Verstraten, J.M.., 2002. Spatial variability of thoughfall water and chemistry and forest floor water content in a Douglas fir forest stand. Hydrol. Earth Syst. Sci. 6, 363-374.

Tietema, A., 1999. Nitraatuitspoeling in een intrekgebied bestudeerd met een dynamisch GIS. (In Dutch). Netherlands Centre for Geo-ecological Research. Internal Report 99/2, University of Amsterdam, Amsterdam, The Netherlands. 50pp.

Tietema, A. and Beier, C., 1995. A correlative evaluation of nitrogen cycling in the forest ecosystems of the EC projects NITREX and EXMAN. Forest Ecol. Manage., 71, 143-151.

Tietema, A., Emmett, B.A. and Cosby, B.J., 1998. Applying MERLIN for modelling nitrate leaching in a nitrogen saturated Douglas fir forest in the Netherlands after decreased atmospheric nitrogen input. Hydrol. Earth Syst. Sci., 2, 431-438.

Tiktak, A. and Bouten, W., 1992. Modelling soil water dynamics in a forested ecosystem. III: Model description and evaluation of discretisation. Hydrol. Process., 6, 455-465.

Van Breemen, N., Burrough, P.A., Velthorst, E.J., Van Dobben, H.F., De Wit, T., De Ridder, T.B. and Reijnders, H.F.R., 1982. Acidification from atmospheric ammonium sulphate in forest canopy throughfall. Nature, 299, 548-550.

Van Dam, D. and Van Breemen, N., 1995. NICCCE: a model for cycling of nitrogen and carbon isotopes in coniferous forest ecosystems. Ecol. Model., 79, 255-275.

Whitehead, P.G., Wilson, E.J. and Butterfield, D., 1998. A semidistributed Integrated Nitrogen model for multiple source assessment in Catchments (INCA): Part 1 - model structure and process equations. Sci. Total Envir., 210/211, 547-558. 